\title{
Poukázka jako cenný papír
}

\section{Warrants as Securities}

\author{
Matěj Dobeš*
}

\begin{abstract}
Abstrakt
Nový občanský zákoník vyvolal pochybnosti obledně právni podstaty poukárky. V některých publikacích již bylo poukázáno na to, že právni úprava poukázky obsažená v ustanoveni \ 1939 a násl. zákona c. 89/2012 Sb., občanskébo zákoníku, by mobla odpovidat definici cennébo papíru. Př̌spèvek reaguje na tyto publikace a klade si za cíl prìspèt do diskuse na dané téma.
\end{abstract}

\section{Klíčová slova}

Poukázka; cenné papiry.

\begin{abstract}
New Civil Code has raised doubts as to the legal nature of warrants. Some scholarly articles have already pointed out that the legislation contained in provision $\int 1939$ et seq. of Law no. 89/2012 Coll., Civil Code, could potentially resemble the definition of securities. The paper responds to this view and contributes to the discussion on the topic.
\end{abstract}

\section{Keywords}

Warrant; Securities.

\section{Úvod}

Právní úprava poukázky (asignace) je nově systematicky zařazena mezi zpơsoby zániku závazku - zřejmě proto, že častým cílem poukázky je splnění závazku dlužníka (poukazatele) vưči věřiteli (poukazníkovi) prostřednictvím třetí osoby (poukázaného). ${ }^{1}$ Sám zákonodárce komentoval tuto změnu tak, že byla odstraněna dřívější „,vadná“ systematika převzatá nesprávnou inspirací v kodexu rakouském. ${ }^{2}$

Kromě toho přinesl (nový) občanský zákoník také možnost vystavit poukázku na řad nebo na doručitele $\left(\int 1939\right.$ odst. 2 NOZ) ${ }^{3}$ a povinnost poukázaného plnit jen proti vydání kvitované poukázky (\$ 1944 odst. 2 NOZ).

\footnotetext{
* Mgr. Matěj Dobeš, asistent, Katedra občanského práva, Právnická fakulta Masarykovy univerzity, Brno / Instructor, Department of Civil Law, Faculty of Law, Masaryk University, Brno, Czech Republic / E-mail: Matej.Dobes@law.muni.cz

1 FIALA, J. In: HENDRYCH, D., FIALA, J. Práunický slownik. 3. vyd. Praha: C. H. Beck, 2009.

2 Vláda: Důvodová zpráva k zákonu č. 89/2012 Sb., občanský zákoník, č. 89/2012 Dz.

3 Zákon č. 89/2012 Sb., občanský zákoník.
} 
V odborných publikacích již bylo poukázáno na to, že „vzhledem k obsahu práv, která jsou s ní spojena, a s ohledem na její převoditelnost ${ }^{\text {“4 }}$ by měla být poukázka nově považována za cenný papír. Některá literatura poukázku dokonce za cenný papír bez dalšího označuje. ${ }^{5}$ Ačkoli je právní podstata poukázky otázkou zcela zásadní (alespoň ve vztahu $\mathrm{k}$ samotné existenci tohoto právního institutu), důvodová zpráva k ní mlčí - neobsahuje žádné informace, které by pojetí poukázky jako cenného papíru potvrzovaly nebo vyvracely. Nekomentuje povinnost poukázaného plnit jen proti vydání kvitované poukázky, možnost poukazatele vystavit poukázku na řad nebo na doručitele, ani převod pohledávky potvrzené listinou, na který se má právní úprava poukázky použít obdobně (『1948 NOZ).

\section{Cenný papír podle občanského zákoníku}

Do účinnosti (nového) občanského zákoníku neobsahoval právní řád České republiky (stejně jako většina všech zahraničních právních řádů) legální definici cenného papíru. Ustanovení \1 ZCP ${ }^{6}$ vymezovalo kategorii cenných papírů pouze prostřednictvím demonstrativního výčtu podmnožin (jednotlivých druhů cenných papírů), nikoli pomocí skupiny charakteristických znaků: „Tento zákon se vatabuje na cenné papiry, kterými jsou zejména akcie, zatimni listy, poukázky na akcie, podilové listy, dlubopisy, investični kupóny, kupóny, opční listy, smènky, šeky, náložné listy, skeladistní listy a žemèdèlské skladni listy. “

Podle \514 NOZ je cenným papírem, ,listina se keterou je právo spojeno takovým zpuisobem, že je po vydáni cenného papiru nelze bez, této listiny uplatnit ani prevést". Ve své podstatě se jedná o Randovu definici cenného papíru z konce 19. století: „Jestli jisté právo s listinou - obsabu jeho naznačujici - takovým zpisobem sloučeno, že právem toliko prostrednictvím listiny vládnouti možno jest, tudǐz zcizeni a jakýkoliv výkon práva jedinè listinou se zprostredkuje, mluvíme o »cenných papirech« (Werthpapiere)".7 Tomuto pojetí odpovídá zásada, že „dispozice s papirem se rovná dispozici s právem", nebo jinými slovy: právo k papíru následuje právo z papíru (Recht am Papier folgt dem Recht auf dem Papier).

Z toho vyplývají následující definiční znaky cenného papíru: 1) spojení práva s listinou, 2) nutnost předložení listiny při uplatnění tohoto práva a 3) nutnost uplatnění listiny př́i jeho prevodu. ${ }^{8}$

Spojení práva s listinou (inkorporace práva do hmotného substrátu) znamená oddělení práva od osoby a přiznání zvláštního hmotněprávního významu cennému papíru.

4 MAREK, R. In: MAREK, R., JEŽEK, V. Cennépapiry v novém občanském qákoníku. Komentár. 1. vyd. Praha: C. H. Beck, 2013, s. 299.

5 VÍTEK, J. In: KOTÁSEK, J., PIHERA, V., POKORNÁ J., VÍTEK, J. Právo cenných papiri. 1. vyd. Praha: C. H. Beck, 2014, s. 42.

6 Zákon č. 591/1992 Sb., o cenných papírech.

7 RANDA, A. O cenných papírech, obzvláště skripturních obligacích. Právník, 1889.

8 K tomu srov. KOTÁSEK, J. In: MELZER, F., TÉGL, P. a kol. Občanský zákoník. \419-564 a souvisejicí společná a prechodná ustanovení. Velký komentár. Svazeek III. Praha: Leges, 2014, s. 378. 
Představuje-li cenný papír skutečnou inkorporaci (zvěcněnî) určitého práva, které nelze mimo tento papír uplatnit a zároveň ani převést, mluvíme o dokonalých cenných papírech ${ }^{9}$ (případně papírech veřejné víry, cenných papírech v užším slova smyslu nebo skripturách). Mezi dokonalé cenné papíry patří cenné papíry na řad a na doručitele.

Cenné papíry na jméno (rektapapíry) nepatří mezi dokonalé cenné papíry, nebot' jim chybí třetí definiční znak cenného papíru uvedený výše. Podle ustanovení \1103 odst. 3 NOZ totiž dochází k převodu rektapapíru již samotnou smlouvou; cenné papíry na jméno tedy „bez listiny“ převést lze (nevyžaduje se její předánî). Mluvíme o cenných papírech v širším smyslu.

Jakkoli definice obsažená v ustanovení \514 NOZ nedopadá na cenné papíry na jméno, zákonodárce rektapapíry mezi cenné papíry řadí (k tomu srov. \518 odst. 1 NOZ). Proto je potřeba přijmout závěr, že podle občanského zákoníku je (navzdory výslovnému znění $\int 514$ NOZ) rozhodujícím znakem cenného papíru skutečnost, že pro uplatnění do něj vtěleného práva (a nikoli již pro jeho převod) je potřebná dispozice s papírem. Občanský zákoník tedy proklamuje užší definici cenných papírů, ale pracuje s definicí širší.

\section{Konvenční pojetí poukázky}

V České republice je poukázka tradičně vnímána jako trojstranný právní vztah, jehož podstatou je oprávnění poukazníka vybrat plnění u poukázaného na základě př́kazu poukazatele. Poukázky se tedy účastní tři subjekty: 1) poukazatel, který vystavuje poukázku, 2) poukazník, který je oprávněný z poukázky a 3) poukázaný, který je dlužníkem z poukázky. Mezi těmito subjekty existují tři dílčí právní vztahy (bez kterých nemůže poukázka vzniknout): valutový, úhradový a platební.

K tomuto komentářovému ${ }^{10}$ pojetí se přihlásil i Nejvyšší soud, když ve svém rozhodnutí ze dne 25. února 2009, sp. zn. 23 Cdo 645/2007, konstatoval následující: „K účinnosti poukázky ve vžtahu ke všem jejím účastnikim se vyžaduji celkem trí právni úkony. Prvním je dohoda mezi poukazatelem a poukaznikem. Právni vztah mezi nimi (valutový pomèr) vzniká, jakmile poukaznik. prïjme zmocnèni poukazatele, a soublasi tedy s tim, že vybere (prijme) plnèni od poukáazanébo. Z tohoto poméru vyplývá divvod (kauza), proč ponkazatel vystavil poukážku (např. splnèni dlubu, darování, poskytnuti pijčkey apod.) a proč poskytuje poukaznikovi určitou bodnotu (valutu), spočivajici v plnèni od poukázanébo. Dalši právni úkon predstavije dohoda mezi poukazatelem a poukázaným. Poukazatel zmocní zároveñ poukázanébo, aby plnil poukaznikovi na účet poukazatele. Tím, že poukázaný zmocnèni prìme (soublasi, že bude plnit poukaznikovi), vaniká mezi nim a poukazatelem právni vžtah (krycí či úbradový pomèr). Poukázaný nemusi prïjmout zmocnèni poukazatele. Jedinè v prĭpadè,

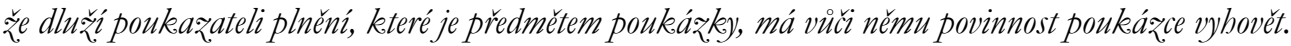

9 Rozsudek Nejvyššího soudu České republiky ze dne 6. 9. 2000 sp. zn. 29 Cdo 901/2000.

10 ŠKÁROVÁ, M. In: ŠVESTKA, J., SPÁČIL, J., ŠKÁROVÁ, M., HULMÁK, M. a kol. Občanský qákoník. I., Komentár. 1. vyd. Praha: C. H. Beck, 2008, s. 143. 
Tretím právnim úkonem je úkon ponkázaného adresovaný poukaznikovi - prịetí ponkázky. Okamžikem, kdy poukaznikovi dojde oznámeni poukázanébo, že poukázku prijimá, vaniká právni vatah mezi nimi (platebni pomèr). Poukaznik timto okamžikem nabývá prímý právni nárok proti poukázanému, takž̃e mưže nárok na plnèni proti nèmu uplatnit žalobou u soudu. Poukázanému vznikla totiž povinnost splnit poukaznikovi to, ke čmu ho poukazatel zmocnil. Jestliže poukázaný plni poté, co byl k tomu poukaznikem vyzuán, má se za to, že poukázku prijal."

Vzhledem k tomu, že forma právních jednání, na jejichž základě vznikají uvedené poměry (tj. dohoda poukazatele s poukazníkem, dohoda poukazatele s poukázaným a oznámení poukázaného poukazníkovi), není zákonem předepsána, bývá tradičně dovozováno, že tato jednání mohou být učiněna i ústně. ${ }^{11}$

\section{Poukázka jako cenný papír}

Dle nekonvenčního pojetí by mohla být poukázka považována za cenný papír, do kterého je inkorporováno právo na plnění toho, co je předmětem poukázky, nebo jako institut některé znaky cenného papíru vykazující (spojení práva s listinou, nutnost předložení listiny při uplatnění tohoto práva a nepravidelně i nutnost uplatnění listiny při jeho převodu).

Tomuto závěru by nasvědčovala např́iklad skutečnost, že poukázaný je povinen plnit jen proti vydání poukázky (\1939 odst. 2 NOZ), poukazatel může vystavit poukázku i na řad nebo na doručitele ( 1939 odst. 2 NOZ), poukázka na řad je převoditelná rubopisem (\} 1 9 4 6 \text { odst. } 1 \text { NOZ), rubopisem přecházejí všechna práva z poukázky na oso- } bu oprávněnou z rubopisu ( $\int 1946$ odst. 2 NOZ), a poukázka na doručitele legitimuje k vybrání plnění každou osobu, která poukázanému poukázku předloží (\$ 1947 NOZ). $\mathrm{V}$ rozporu s tímto závěrem je naopak absence výslovného ustanovení ohledně formy (\559 NOZ), možnost poukazatele odvolat poukázku (\1942 NOZ) a především konvence, tedy skutečnost, že poukázka tradičně není považována za cenný papír, a ani zákonodárce $\mathrm{v}$ důvodové zprávě na žádnou změnu v tomto směru neupozornil.

Zákon neřeší ani otázku, zda je listina podmínkou existence poukázky (at' už „,cenná“ či nikoli). Nabízí se závěr, že poukázku na řad a na doručitele (『 1939 odst. 2, \1946 a $\int 1947$ NOZ) bude potřeba vyhotovit na listinu, tedy v písemné formě konkretizované do podoby listiny, která splňuje určité náležitosti ( $\int 515$ NOZ). Tím se však stává spornou otázka, zda poukázka může být sjednána mimo listinu, tedy v obecné písemné formě nebo ústně (i když se jedná o konvenční pojetî). Vzhledem k tomu, že podle \559 NOZ může každý právně jednat v libovolné formě, není-li ve volbě formy omezen ujednáním nebo zákonem, lze při absenci výslovného požadavku na formu předpokládat, že poukázku lze sjednat i mimo listinu. K tomuto závěru ostatně dospěla i prvorepubliková judi-

11 Např. DÁVID, R. In: HULMÁK, M. a kol. Občanský quákoník. V. Závaẓkové právo. Obecná cuást (』 1721-2054).

Komentár. 1. vyd. Praha: C. H. Beck, 2014. 
katura. ${ }^{12} \mathrm{~V}$ takovém př́ipadě je naopak zjevné, že právo nebude inkorporováno do listiny, ale bude náležet osobě. Koncepce poukázky jako listiny však není bezproblémová, nebot' \1942 NOZ upravuje možnost poukazatele odvolat poukázku: odvolání poukázky by naopak konvenovalo s pojetím poukázky jako klasického závazkového vztahu.

Ustanovení \ 1944 odst. 2 NOZ, podle kterého je poukázaný povinen plnit jen proti vydání kvitované poukázky (ke kvitanci srov. \1949 a násl NOZ), je v absolutním rozporu s konvenčním vnímáním poukázky. Jestliže zákon explicitně stanoví, že poukázaný není povinen plnit mimo listinu, je potřeba dovodit existenci této listiny nutné k uplatnění práva, protože jinak postrádá celý institut na významu (poukázaný je oprávněn odepřít plněnî). Není však žrejmé, o jakou listinu se jedná. Výše bylo uvedeno, že ani pro právní jednání, kterými vzniká valutový, úhradový a platební poměr, zákon nevyžaduje písemnou formu. Pojem kvitované poukázky tedy nelze vykládat např́klad ve smyslu kvitovaného písemného oznámení o přijetí poukázky (př́padně jiného právního jednání dávajícího za vznik poukázce), nebot’ žádné takové listiny není ke vzniku poukázky zapotřebí. Uvedené dilema by se dalo překlenout výkladem, podle kterého je poukázaný povinen plnit proti vydání „kvitance“. Za smysluplnější lze však považovat závěr, který odporuje konvenčnímu pojetí, totiž že poukázka musí být vyhotovena na listinu (což je ostatně nevyhnutelné minimálně u poukázky na řad a na doručitele), a že tato listina je nutná k uplatnění práva, které je do ní inkorporováno.

$\mathrm{K}$ nutnosti vyhotovení poukázky na listinu lze dále uvést, že zákon hovoří výslovně o „vystavení“ poukázky (〔 1939 odst. 2 NOZ). Kdyby poukázka představovala klasický závazkový vztah, zákon by nemluvil o jejím vystavení, nýbrž „ujednáni“. Z jazykového hlediska lze pozorovat, že se vystavuje spíše směnka a šek (\1909 NOZ), záruční listina (\2039 odst. 1 NOZ), skladištní list (\2417 odst. 1 NOZ), náložný list (\$ 2572 odst. 3 NOZ) nebo vkladní knížka (\2676 odst. 1 NOZ).

Existuje tedy relevantní důvod pro to, aby byla poukázka vnímána jako listina nutná k uplatnění práva. Tím by byl naplněn první a druhý definiční znak cenného papíru, což by samo o sobě stačilo k zařazení poukázky mezi cenné papíry v širším pojetí (viz výše). Třetí definiční znak cenného bude přítomný u poukázky na řad a na doručitele, které by bylo možné považovat za dokonalé cenné papíry.

Podle \1939 odst. 2 NOZ lze poukázku vystavit i na řad nebo na doručitele. Tato klasifikace odpovídá právní úpravě cenných papírů, u kterých rozlišujeme mezi formou na řad, na jméno a na doručitele ( $\int 518$ odst. 1 NOZ). Vzhledem k tomu, že poukázku lze vystavit „¡“ na řad a na doručitele, lze dovozovat, že základní formou poukázky bude poukázka na jméno.

Pro poukázku na řad platí, že rubopisem přecházejí všechna práva „z poukázky“ na osobu oprávněnou z rubopisu (\$ 1946 odst. 2 NOZ). Přecházejí tedy práva inkorporovaná do poukázky. Nepřecházejí z indosanta, nýbrž z poukázky (lze opět usuzovat na spojení práva s listinou).

12 Nejvyšší soud Československé republiky, Rv I 868/25, [Vážný 5370]. 
$\mathrm{K}$ převodu poukázky na řad rubopisem se vyžaduje uzavření smlouvy mezi převodcem (indosantem) a nabyvatelem (indosatářem), vyhotovení rubopisu a předání (tradice) poukázky nabyvateli ( $\$ 1103$ odst. $2 \mathrm{NOZ}$ ). K převodu poukázky na řad je potřeba předání poukázky jejímu novému nabyvateli, což znamená, že převedení práva, které je do poukázky na řad inkorporováno, není možné mimo listinu. Majiteli poukázky musí svědčit i obsah poukázky - musí být z poukázky legitimován. Legitimován je potom zásadně jen tehdy, drží-li poukázku v rukou a svědčíli mu nepřetržitá řada rubopisů ( $\mathbb{1 6}$ odst. 1 ZSŠ ${ }^{13}$ prostřednictvím $\ 1946$ odst. 3 věty první NOZ) s tím, že pokud tuto řadu uzavírá blankoindosament, postačí pouhé držení poukázky. $V$ žádném př́padě nepůjde poukázku na řad uplatnit bez jejího předložení, což si zákon uvědomuje, když řeší situaci, od koho lze požadovat ztracenou poukázku na řad ( $\$ 1946$ odst. 3 věta druhá NOZ). Byla-li poukázka vystavena na doručitele, zaplatí poukázaný dluh každému, kdo poukázku předloží ( 1947 NOZ). Poukázka na majitele je neomezeně převoditelná pouhým předáním (blankotradicî). Smysl doložky „na doručitele“ spočívá v tom, že k výkonu práva, které je do poukázky inkorporováno, je legitimován každý držitel. Z toho vyplývá, že právo z poukázky na doručitele nelze mimo listinu uplatnit ani převést.

V rozporu s pojetím poukázky jako cenného papíru zůstává absence výslovného prohlášení poukázky za cenný papír, nestanovení podstatných náležitostí poukázky a možnost odvolat poukázku (cenný papír lze stáhnout $\mathrm{z}$ oběhu, ale nelze jej odvolat $-\mathrm{k}$ tomu srov. \1942 NOZ). V neposlední řadě je to také konvence, tedy skutečnost, že poukázka tradičně není považována za cenný papír, a ani zákonodárce v důvodové zprávě na žádnou změnu $\mathrm{v}$ tomto směru neupozornil.

\section{Závěr}

Novou právní úpravu poukázky je zřejmě potřeba označit za legislativní zmetek, nebot' postrádá vnitřní logiku. Zahrnuje v sobě jak ustanovení, která by odpovídala povaze skripturní obligace, tak ustanovení, která by odpovídala klasickému závazkovému vztahu, přičemž pochybnosti nelze uspokojivě překlenout ani výkladem. Nelze tedy než doporučit novelu (nového) občanského zákoníku, která právní podstatu poukázky vyjasní. Pojetí poukázky jako listiny (cenného papíru) by mohlo být pro praxi široce využitelné (viz např. stravenky, jízdenky, vstupenky nebo slevové kupóny, jejichž právní povaha je sporná). Poukázka jako cenný papír by nejblíže připomínala směnku cizí: ${ }^{14}$ na rozdíl od směnky cizí však poukázka nemusí znít pouze na zaplacení peněžité částky, ale může znít například na poskytnutí zboží nebo služby. Dalším významným rozdílem je i možnost vystavení poukázky na doručitele.

\footnotetext{
13 Zákon č. 191/1950 Sb., směnečný a šekový.

14 GRULICH, T. O poukázce. Právní roz̧bledy, 2011, č. 1.
} 